\title{
浅析建筑工程招投标阶段的造价控制
}

唐秋香

广西弘凰投资有限公司

DOI:10.18686/bd.v2i4.1314

[摘 要] 建筑工程招投标阶段造价控制是为建筑工程设计提供合理、准确的项目工程预算, 以便确定投资规模,合理安排 资金,并确保预算不超概算,并且是工程施工阶段工程造价控制的依据。因此如何对工程项目招投标阶段的造价进行有效控 制,关系着整个工程项目的建设周期的缩短, 工程质量的提高,建设资金的节约及投资效益的提高。基于此,本文简述了建筑 工程招投标阶段造价控制的重要性,对建筑工程招投标阶段造价控制存在的问题及其措施进行了探讨分析。

[关键词] 建筑工程; 招投标阶段; 造价控制; 重要性; 问题; 措施

建筑工程建设实施招投标是为了适应市场经济发展的 客观要求,并且是为了优化工程建设资源配置以及低成本、 高质量完成工程建设。为了充分发挥其作用, 以下就建筑工 程招投标阶段的造价控制进行了探讨分析。

\section{1 建筑工程招投标阶段造价控制的重要性}

建筑工程招投标阶段造价控制可以实现概算、预算控 制, 从而降低成本。建筑工程招投标阶段阶段的造价控制, 要 求投标方学会事前主动控制, 最大程度降低市场价格波动 风险、设计风险、物资采购风险、施工管理风险等,利用财务 决策、经济学等理论、投标报价技巧, 在保证质量的前提下, 合理确定投标报价, 提高中标可能。建筑工程招投标阶段主 要产生签约合同价,合同价受法律约束, 对后期结算影响极 大。因此合理控制这一阶段的工程造价,一定程度上可以避 免工程施工过程中不必要的纠纷以及竣工后的索赔事件。

\section{2 建筑工程招投标阶段造价控制存在的主要问题}

建筑工程招投标阶段造价控制存在的问题主要有

2.1 招投标文件编制问题。建筑工程招投标阶段在编制 招投标文件时,如果招投标文件的编制有问题,会使项目的 时间成本和资金成本大大增加, 不利于项目造价控制, 具体 体现在以下方面: 招标文件中,文件内容前后不一致,相差很 大; 工程量清单没有严格审核, 存在错项、漏项、重项, 项目特 征描述不全面,计算错误等; 合同条件不明确; 招标控制价 没有全面分析等。投标文件中, 未响应招标文件的某些实质 性内容等。

2.2 招投标阶段的投标问题。主要有:第一,盲目投标。 投标单位不仔细分析招标文件, 不认真阅读其中的实质性 内容就编制投标文件, 可能增加编制投标文件的费用,后期 面临变更时也会使整个项目的造价超过预期。第二, 不规范 的竞标行为。比如低价中标, 高价结算; 不合理的设计变更、 签证索赔; 偷工减料, 以次充好, 低价购进, 高额报价等。第三, 违法现象严重。比如围标串标陪标、以贿赂手段获取标底、 权力标、关系标等,这严重扰乱了正常交易的秩序。

2.3 招投标阶段的评标问题。建筑工程招投标阶段的评 标工作是招投标竞争结果的重要过程。其一, 从评标委员会
的建立而言, 虽然我国法律规定了评标人员的选取, 但其在 评价投标文件时, 由于专业水平及掌握的专业信息有区别, 以及投标单位的知名度不同, 所以在评标时有一定的主观 倾向性。其二,评标方法不全面。目前我国采用经评审的最 低报价法和综合报价法, 二者各有其适用范围及优点, 但任 一方法都很难满足项目方方面面的需求, 可能直接导致评 标结果的不合理。

\section{3 建筑工程招投标阶段造价控制的措施}

3.1 合理编制招标文件。具体表现为

3.1.1 明确合同条款内容。主要的合同条款有工程质 量、质量验收标准、工期要求以及费用结算办法等。对于质 量要求, 是合格还是优良, 是否要求该工程项目获得什么奖 项,都应该明确提出。不同的质量要求,投标人会采取不同的 技术措施,所产生的费用也就不同. 对于工期要求,一般的工 程项目都是按照定额工期来执行的, 但是对于一些特殊工 程项目要求提前工期的, 应该在招标文件中明确提出来, 以 免日后成为中标单位进行索赔的依据。

3.1.2 详细描述材料设备特征。建筑工程建设过程中的 每种材料、设备种类很多,而且生产这些材料、设备的厂家 规模大小不一, 所以它们的价格也会相差很大. 因此, 尤其对 于那些市场价格差异较大的设备、材料的型号、功能、等级、 外观色彩和质量要求应标注清楚, 可以约定一个上限价格, 并且要求承包人必须在施工前提供样品, 得到业主的认可 后方能施工。以确保施工方不会以次充好, 保证建筑产品的 质量。

3.1.3 明确编制招标文件的各项条款要求和含义, 不能 留下含糊可产生歧义的解释, 确保能全面反映工程项目实 际的要求. 招标单位还应对所招标的工程项目概况、功能特 征和招标范围进行准确描述. 若表达的内容不清楚,可能会 在工程结算时由于误解而产生误会,使得工程造价增加。

3.2 严格投标人诚信控制。首先明确哪些行为属于非诚 信行为, 并以文件形式发布在市场中. 其次, 制定投标人的诚 信评价体系, 它是现代市场体系的重要组成部分, 既有利于 业主的招标工作, 又是政府管理部门进行市场监控的有效 
工具。投标人的诚信评价体系可以从投标人的企业状况如 资金能力、经营能力、技术素质、人员素质等、投标人的履约 信誉如投标人按最低价中标后的履约情况、支付民工工资 情况等两个方面来人手。再次,建立诚信惩戒机制,将投标人 在投标过程中和合同履行过程中存在的各种失信行为一一 记录备案,建立诚信档案,同时还要把有严重失信问题的投 标企业列人到黑名单,并在社会上进行公布. 当投标企业的 失信次数达到一定次数或者产生了恶劣的社会影响时,行 政监督部门可以在一定的期限内取消投标企业从事投标活 动的资格,直至吊销其相关资质。这一措施把投标企业的诚 信状况与其以后的投标工作进行挂钩, 能够把没有诚信的 投标企业直接拒之于竞争者的行列之外, 将工程项目交给 真正有诚信的投标企业，这即提升了诚信好的投标企业的 社会信誉, 又制裁了不守诚信的投标企业,真正规范了建筑 市场的招标行为。

3.3 加强工程量清单的规范编制。主要表现为

3.3.1 工程量清单的科学编制要准确完整的描述工程 项目特征与工作内容。工程量清单的科学编制过程中,需要 详细描述项目特征和工作内容, 并且对于有关结构要求的 内容必须要描述清楚, 如硅的强度等级; 对于涉及到计量的 内容必须要描述,如门窗洞口的尺寸; 对于有质量要求的内 容必须要描述, 如涂料品种; 对于关于安装和铺贴方式的内 容必须要描述,如砖块的铺贴方式等。

3.3.2 工程量清单的科学编制要结合工程施工图纸、技 术规范和施工现场实际,并严格依据《建筑工程工程量清单 计价规范》的工程量计算规则进行清单的计算与编制。保证 工程量清单项目不错项、不漏项, 确保工程量计算的正确 性。由于有些清单项目综合性较强, 有时一个清单项目包含 了好几个子目的内容, 如瓦屋面综合了擦条安装、基层铺 设、防水层铺设、挂瓦条安装、瓦的铺设、脊瓦的铺设等内 容,因此,在编制工程量清单时应根据要求仔细分项,争取做 到不错项、不漏项、不多算、不少算和不留缺口,防止日后施 工阶段追加工程造价。

3.4 推行电子招投标。推行电子招投标有利于规范招投 标各方行为,维持公开、公平、公正的招投标秩序。通过客观 的技术手段,一定程度上避免暗箱操作、贪污腐败、串标围 标等现象,推动招投标行业的发展。电子招投标不仅降低了
招投标程序自身的成本,还为客户节约了更多的资源。据科 学研究调查报告显示, 约 70\%以上的世界 500 强企业已加 人到电子招投标的使用。电子招投标的管理更趋于客观化, 对招投标各方文件的编制与审核更系统化, 有利于控制招 投标阶段的工程造价。

3.5 完善评标体系。具体体现在

3.5.1 重视技术标的评审。包括施工组织设计、施工方 案、施工进度计划、项目质量、工期、企业业绩及信誉等。

3.5 .2 合理评估商务标。评审时要根据清单工程量、市 场价、地方或企业定额等合理分析投标报价,尤其是占总造 价 $70 \%$ 的建筑材料费。

3.5.3 落实询标工作。在开标后评标前, 应通过询标了解 技术、设备、管理等方面的实际水平,对投标文件不明确的 内容进行书面澄清、说明或补正。

3.5.4 引进 “德尔菲法”进行评标。对投标文件进行统一 编号,隐藏各投标单位身份的信息,让各评标成员在互不干 扰的情况下,合理评出最佳中标候选人。同时应建立责任制, 评标人员应对自己的评价担责。

3.5.5 多种评价方法并存。在条件允许的情况下, 运用多 种方法来综合确定中标候选人,避免劣胜优汰。

\section{4 结束语}

综上所述, 建筑工程管理中的招投标阶段造价控制, 关 系着建筑工程项目的建设周期的缩短、工程质量的提高以 及建设项目资金的节约与投资效益的提高, 因此加强对建 筑工程管理中的招投标阶段造价控制进行分析具有重要意 义。

\section{参考文献:}

[1]罗天旋.浅议建筑工程招标投标阶段造价控制 [J]. 装饰装修天地,2016(03):25.

[2]王华.浅析工程招标阶段的造价控制 [J]. 财经界(学 术版),2016(11):60.

[3] 汪洋. 关于招投标阶段的工程造价控制问题探析 [J].经济师,2015(01):285-286.

[4]陈泽远.建筑工程招投标阶段的造价控制措施 [J]. 建筑知识,2017(01):2

[5]马安林. 建筑工程招标投标阶段的造价管理控制 [J].建材与装饰,2018(14):211-212. 